\title{
Soil Chemical Properties Barely Perturb the Abundance of Entomopathogenic Fusarium oxysporum: A Case Study Using a Generalized Linear Mixed Model for Microbial Pathogen Occurrence Count Data
}

\author{
Lav Sharma ${ }^{1, *}$, Irene Oliveira ${ }^{1,2}\left(\mathbb{C}\right.$, Fernando Raimundo ${ }^{1}\left[\right.$, Laura Torres ${ }^{1}(\mathbb{D}$ \\ and Guilhermina Marques ${ }^{1}$ \\ 1 CITAB - Centre for the Research and Technology of Agro-Environmental and Biological Sciences, \\ University of Trás-os-Montes and Alto Douro, UTAD, 5001-801 Vila Real, Portugal; ioliveir@utad.pt (I.O.); \\ fraimund@utad.pt (F.R.); ltorres@utad.pt (L.T.); gmarques@utad.pt (G.M.) \\ 2 CEMAT-IST-UL-Centre for Computational and Stochastic Mathematics, University of Lisbon, \\ 1649-004 Lisbon, Portugal \\ * Correspondence: 1sharma@utad.pt; Tel.: +351-259-350-2472
}

Received: 30 September 2018; Accepted: 31 October 2018; Published: 16 November 2018

\begin{abstract}
Fusarium oxysporum exhibits insect pathogenicity-however, generalized concerns of releasing phytopathogens within agroecosystems marred its entomopathogenicity-related investigations. In a previous study, soils were sampled from Douro vineyards and adjacent hedgerows. In this study, 80 of those soils were analyzed for their chemical properties and were subsequently co-related with the abundance of entomopathogenic F. oxysporum, after insect baiting of soils with Galleria mellonella and Tenebrio molitor larvae. The soil chemical properties studied were organic matter content; total organic carbon; total nitrogen; available potassium; available phosphorus; exchangeable cations, such as $\mathrm{K}^{+}, \mathrm{Na}^{+}, \mathrm{Ca}^{2+}$, and $\mathrm{Mg}^{2+} ; \mathrm{pH}$; total acidity; degree of base saturation; and effective cation exchange capacity. Entomopathogenic F. oxysporum was found in 48 soils, i.e., $60 \% \pm 5.47 \%$, of the total soil samples. Out of the 1280 insect larvae used, 93 , i.e., $7.26 \% \pm 0.72 \%$, were found dead by entomopathogenic F. oxysporum. Stepwise deletion of non-significant variables using a generalized linear model was followed by a generalized linear mixed model (GLMM). A higher C:N (logarithmized) $(p<0.001)$ and lower exchangeable $\mathrm{K}^{+}$(logarithmized) $(p=0.008)$ were found significant for higher fungal abundance. Overall, this study suggests that entomopathogenic F. oxysporum is robust with regard to agricultural changes, and GLMM is a useful statistical tool for count data in ecology.
\end{abstract}

Keywords: entomopathogenic fungi; soil chemistry; microbial ecology; vineyards; Fusarium oxysporum; generalized linear mixed model

\section{Introduction}

Entomopathogenic fungi are the natural biological control agents of insect pests [1]. The fungi belonging to Fusarium Link ex Grey (Hypocreales: Nectriaceae) are widely known as plant pathogens and saprophytes. Among animals, Fusarium spp. are quite abundantly associated with insects from different orders, i.e., Coleoptera, Diptera, Hemiptera, Isoptera, Lepidoptera, and Orthoptera [2,3]. A previous study emphasized the use of different Fusarium spp. as biological control agents for the agricultural insect pests, and aroused concern towards the limited research in this direction, pertaining to a generalized apprehension of releasing phytopathogens and related toxins in the environment [4]. 
The commonly occurring fusaria from insects were termed "insecticolous fungi" [4]. Another study suggested that Fusarium spp., which can kill insects, can be good candidates for insect biological control in agroecosystems. Because these fusaria sometimes demonstrate high host specificity, can be easily cultured in a laboratory setting, can survive in fields as facultative pathogens, and are not all harmful to plants [5].

Fusarium oxysporum Schlechtendahl is a widely known pathogen of plants and animals, including infections in humans; however, safe fusaria also exist in nature. Previous studies provide compelling reasons to consider fungi like $F$. oxysporum for biological control of insect pests $[4,5]$. Another recent study presented a detailed dose-response curve and histological evidence of $F$. oxysporum infections, and subsequent mortalities, in the larvae of wax moth Galleria mellonella Linnaeus (Pyralidae: Lepidoptera) [6]. Therefore, it was a proof-of-concept study demonstrating the entomopathogenicity of F. oxysporum.

Soil is an excellent reservoir of insect-pathogenic fungi (IPF). However, only a few studies report the effects of physicochemical properties of soil on the distribution of IPF. Previous studies in this direction primarily focused on IPF Beauveria bassiana (Balsamo) Vuillemin (Hypocreales: Cordycipitaceae), and Metarhizium anisopliae (Metschnikoff) (Hypocreales: Clavicipitaceae) [7-12]. According to our knowledge, to date there is no report that focuses on soil chemical properties in terms of the abundance of IPF F. oxysporum.

In this study, authors analyzed the chemical properties of the soils, including percentage organic matter content $(\mathrm{OM})$; total organic carbon $(\mathrm{C})$; total nitrogen $(\mathrm{N})$; available potassium $(\mathrm{K})$; available phosphorus $(\mathrm{P})$; exchangeable ions such as potassium $\left(\mathrm{K}^{+}\right)$, sodium $\left(\mathrm{Na}^{+}\right)$, calcium $\left(\mathrm{Ca}^{2+}\right)$ and magnesium $\left(\mathrm{Mg}^{2+}\right)$; $\mathrm{pH}$ in $\mathrm{H}_{2} \mathrm{O}$; total acidity (TA); degree of base saturation (DBS); and effective cation exchange capacity (ECEC), and investigated their effects on the natural abundance of entomopathogenic F. oxysporum. To enhance variations in the chemical properties, different soils were considered. Soils were (a) different in texture-i.e., medium-texture (more balanced mixture of sand, silt, and clay) or coarse-texture (high proportion of sand)—(b) sampled from varying habitat types-i.e., cultivated vineyards or adjacent hedgerows, mainly constituted of oak (Quercus spp. Linnaeus, Fagaceae) and pine trees (Pinus spp. Linnaeus, Pinaceae)-and (c) either treated with herbicides or left untreated.

Statistical modeling has been useful in entomology and related studies [13,14]. The generalized linear mixed model (GLMM) is a widely known tool in ecology for count data [15]. In terms of IPF, count data is of great relevance; however, investigations implementing GLMM to study IPF occurrences are limited [16].

The objectives of this work were (a) to understand the effects of soil chemical properties on IPF $F$. oxysporum occurrences in the soil, and (b) to demonstrate the usefulness of GLMM in studying the abundance of microbial pathogens-for example, IPF. This study goes a step further and provides a newer prospective among the ongoing efforts to utilize microbial entomopathogenicity in insect pest biological control within agroecosystems. To the best of our knowledge, this is the first report on the effects of the soil chemical properties with respect to inter-kingdom host pathogen F. oxysporum.

\section{Results}

\subsection{Infection Frequencies}

A total of 80 soils were selected to access the occurrence of entomopathogenic F. oxysporum, in terms of their chemical properties (Table 1). Out of these, 48 samples were found positive for the fungus (i.e., $60 \% \pm 5.47 \%$ ). A total of 93 F. oxysporum strains were isolated and found to be insect-pathogenic, after testing 1280 insect larvae in total-16 larvae in each of the 80 soils. The frequency of infection among baited larvae by F. oxysporum was $7.26 \% \pm 0.72 \%$. 
Table 1. Soil physicochemical properties of the collected samples, and the numbers of entomopathogenic Fusarium oxysporum encountered.

\begin{tabular}{|c|c|c|c|c|c|c|c|c|c|c|c|c|c|c|c|c|c|c|}
\hline Farm Type & Soil Type & Herbicide Usage & Rapid Texture & Collection Site & OM & $\mathbf{P}$ & $\mathrm{K}$ & $\mathrm{Ca}^{2+}$ & $\mathrm{Mg}^{2+}$ & $\mathbf{K}^{+}$ & $\mathrm{Na}^{+}$ & ECEC & $\mathbf{N}$ & TA & $\mathrm{pH}$ & $\mathrm{C}: \mathrm{N}$ & DBS & $\begin{array}{l}\text { Fusarium oxysporum } \\
\text { Count }\end{array}$ \\
\hline Carvalhas & Vineyards & 0 & Medium & nh1mCa1A & 6.31 & 22 & 139 & 7.94 & 1.55 & 0.68 & 0.10 & 10.36 & 3.01 & 0.10 & 5.9 & 12.155174 & 99 & 1 \\
\hline Carvalhas & Vineyards & 0 & Medium & nh1mCa2C & 4.57 & 6 & 90 & 4.27 & 1.20 & 0.33 & 0.03 & 5.83 & 2.45 & 0.00 & 6.3 & 10.819543 & 100 & 3 \\
\hline Carvalhas & Vineyards & 1 & Medium & $\mathrm{hmCa} 3 \mathrm{~B}$ & 2.21 & 221 & 197 & 3.89 & 0.69 & 0.63 & 0.01 & 5.78 & 1.38 & 0.55 & 5.2 & 9.2963577 & 90 & 2 \\
\hline Carvalhas & Vineyards & 1 & Medium & $\mathrm{hmCa} 4 \mathrm{~A}$ & 1.43 & 46 & 60 & 3.47 & 1.76 & 0.26 & 0.08 & 6.55 & 0.93 & 0.98 & 5.5 & 8.934769 & 85 & 1 \\
\hline Carvalhas & Vineyards & 1 & Medium & $\mathrm{hmCa} 5 \mathrm{~A}$ & 1.39 & 45 & 56 & 4.94 & 1.17 & 0.19 & 0.18 & 6.71 & 0.90 & 0.23 & 5.8 & 8.9326187 & 97 & 1 \\
\hline Carvalhas & Vineyards & 1 & Gross & hgCa6B & 4.15 & 96 & 84 & 1.09 & 0.37 & 0.26 & 0.03 & 4.15 & 2.21 & 2.40 & 4.4 & 10.895056 & 42 & 2 \\
\hline Carvalhas & Vineyards & 1 & Medium & $\mathrm{hmCa} 7$ & 1.24 & 91 & 92 & 4.10 & 1.07 & 0.28 & 0.03 & 6.22 & 0.89 & 0.75 & 5.3 & 8.0555353 & 88 & 0 \\
\hline Carvalhas & Vineyards & 1 & Medium & $\mathrm{hmCa} 8$ & 3.17 & 81 & 147 & 5.06 & 0.91 & 0.48 & 0.06 & 6.99 & 2.04 & 0.50 & 5.2 & 9.0237878 & 93 & 0 \\
\hline Carvalhas & Vineyards & 1 & Medium & hmCa9 & 1.76 & 106 & 118 & 3.33 & 0.67 & 0.40 & 0.02 & 5.72 & 1.22 & 1.30 & 4.9 & 8.3599869 & 77 & 0 \\
\hline Carvalhas & Vineyards & 1 & Medium & hmCa10 & 2.78 & 56 & 74 & 3.68 & 1.24 & 0.27 & 0.06 & 6.22 & 1.81 & 0.98 & 5.0 & 8.894316 & 84 & 0 \\
\hline Carvalhas & Vineyards & 1 & Medium & hmCa11A & 2.57 & 70 & 108 & 3.50 & 0.80 & 0.41 & 0.10 & 6.36 & 1.69 & 1.55 & 4.6 & 8.8276961 & 76 & 1 \\
\hline Carvalhas & Vineyards & 1 & Medium & hmCa12A & 2.74 & 64 & 104 & 6.24 & 1.49 & 0.36 & 0.03 & 8.70 & 1.79 & 0.58 & 5.3 & 8.8875571 & 93 & 1 \\
\hline Carvalhas & Hedgerows & 0 & Medium & nh2mCaM1B & 5.71 & 14 & 86 & 8.17 & 1.43 & 0.37 & 0.07 & 10.25 & 2.90 & 0.00 & 6.4 & 11.438218 & 100 & 2 \\
\hline Carvalhas & Hedgerows & 0 & Medium & nh2mCaM2D & 5.74 & 15 & 90 & 8.14 & 1.60 & 0.39 & 0.06 & 10.19 & 2.83 & 0.00 & 6.2 & 11.758777 & 100 & 4 \\
\hline São Luiz & Vineyards & 1 & Medium & hmSl11 & 4.38 & 174 & 82 & 2.41 & 1.87 & 0.30 & 0.10 & 4.93 & 2.22 & 0.25 & 5.5 & 11.44503 & 95 & 0 \\
\hline São Luiz & Vineyards & 0 & Medium & nh1mSl12 & 1.54 & 37 & 40 & 4.27 & 1.04 & 0.13 & 0.08 & 5.53 & 0.80 & 0.00 & 6.1 & 11.161607 & 100 & 0 \\
\hline São Luiz & Vineyards & 1 & Medium & $\mathrm{hmSl} 21$ & 6.38 & 34 & 72 & 6.09 & 1.71 & 0.25 & 0.05 & 8.09 & 2.96 & 0.00 & 6.2 & 12.492244 & 100 & 0 \\
\hline São Luiz & Vineyards & 0 & Medium & $\mathrm{nh} 1 \mathrm{mSl} 22 \mathrm{~A}$ & 3.41 & 28 & 68 & 3.78 & 0.83 & 0.21 & 0.03 & 4.85 & 1.85 & 0.00 & 6.3 & 10.680227 & 100 & 1 \\
\hline São Luiz & Vineyards & 1 & Medium & hmSl3A & 2.09 & 56 & 50 & 8.10 & 1.65 & 0.14 & 0.08 & 9.96 & 1.21 & 0.00 & 6.8 & 9.9992 & 100 & 1 \\
\hline São Luiz & Vineyards & 1 & Medium & $\mathrm{hmSl} 141 \mathrm{~A}$ & 1.26 & 26 & 58 & 3.46 & 1.09 & 0.14 & 0.06 & 4.74 & 0.79 & 0.00 & 5.9 & 9.2397671 & 100 & 1 \\
\hline São Luiz & Vineyards & 0 & Medium & nh1mSl42 & 2.93 & 43 & 108 & 3.81 & 1.17 & 0.32 & 0.06 & 5.35 & 1.82 & 0.00 & 6.1 & 9.3399121 & 100 & 0 \\
\hline São Luiz & Vineyards & 1 & Medium & $\mathrm{hmSl} 151$ & 6.84 & 45 & 74 & 1.34 & 0.69 & 0.24 & 0.06 & 2.74 & 2.98 & 0.40 & 5.6 & 13.314371 & 85 & 0 \\
\hline São Luiz & Vineyards & 0 & Medium & nh1mSl52 & 3.77 & 25 & 70 & 3.37 & 0.40 & 0.21 & 0.06 & 4.04 & 2.12 & 0.00 & 6.3 & 10.310496 & 100 & 0 \\
\hline São Luiz & Vineyards & 1 & Medium & $\mathrm{hmSl61B}$ & 4.04 & 28 & 46 & 3.12 & 2.61 & 0.18 & 0.17 & 6.14 & 1.94 & 0.05 & 5.8 & 12.086662 & 99 & 2 \\
\hline São Luiz & Vineyards & 0 & Medium & nh1mS162B & 3.13 & 23 & 42 & 4.30 & 2.29 & 0.17 & 0.24 & 7.06 & 1.46 & 0.05 & 5.9 & 12.44421 & 99 & 2 \\
\hline São Luiz & Vineyards & 1 & Medium & hmSl71A & 2.48 & 14 & 48 & 2.85 & 2.56 & 0.16 & 0.15 & 5.79 & 1.23 & 0.08 & 5.3 & 11.690122 & 99 & 1 \\
\hline São Luiz & Vineyards & 0 & Medium & nh1mSl72 & 2.07 & 6 & 52 & 2.45 & 2.56 & 0.15 & 0.13 & 5.36 & 1.11 & 0.08 & 5.5 & 10.809946 & 99 & 0 \\
\hline São Luiz & Vineyards & 1 & Medium & hmSl81A & 1.59 & 38 & 76 & 2.58 & 1.36 & 0.19 & 0.06 & 4.18 & 1.01 & 0 & 6.4 & 9.1081822 & 100 & 1 \\
\hline São Luiz & Vineyards & 0 & Medium & nh1mS182 & 1.90 & 53 & 108 & 1.76 & 0.85 & 0.23 & 0.12 & 2.96 & 1.1 & 0 & 6.0 & 9.9992 & 100 & 0 \\
\hline São Luiz & Vineyards & 1 & Medium & hmSl91 & 1.29 & 42 & 70 & 1.44 & 0.43 & 0.15 & 0.03 & 2.18 & 0.71 & 0.13 & 5.9 & 10.562535 & 94 & 0 \\
\hline São Luiz & Vineyards & 0 & Medium & nh1mSl92 & 1.71 & 51 & 54 & 1.86 & 0.43 & 0.15 & 0.05 & 2.48 & 0.93 & 0 & 6.2 & 10.64431 & 100 & 0 \\
\hline São Luiz & Vineyards & 1 & Medium & hmSl101 & 2.18 & 29 & 74 & 2.43 & 0.67 & 0.22 & 0.06 & 3.38 & 1.19 & 0 & 6.4 & 10.629402 & 100 & 0 \\
\hline São Luiz & Vineyards & 0 & Medium & nh1mSl102 & 4.02 & 20 & 92 & 3.76 & 0.77 & 0.25 & 0.03 & 4.82 & 1.93 & 0 & 6.3 & 12.081935 & 100 & 0 \\
\hline São Luiz & Vineyards & 1 & Medium & $\mathrm{hmSl111 \textrm {B }}$ & 2.31 & 10 & 66 & 7.18 & 1.39 & 0.15 & 0.07 & 8.79 & 1.29 & 0 & 6.6 & 10.386766 & 100 & 2 \\
\hline São Luiz & Vineyards & 0 & Medium & nh1mSl112A & 2.88 & 45 & 60 & 8.14 & 1.23 & 0.16 & 0.08 & 9.61 & 1.52 & 0 & 6.7 & 10.985963 & 100 & 1 \\
\hline São Luiz & Vineyards & 0 & Medium & nh1mSl112 & 4.22 & 7 & 70 & 11.23 & 1.36 & 0.16 & 0.15 & 12.91 & 2.61 & 0 & 6.8 & 9.3862222 & 100 & 0 \\
\hline São Luiz & Vineyards & 1 & Medium & $\mathrm{hmSl131 \textrm {B }}$ & 2.79 & 50 & 104 & 2.19 & 0.69 & 0.28 & 0.05 & 3.22 & 1.31 & 0 & 6.1 & 12.334891 & 100 & 2 \\
\hline São Luiz & Vineyards & 0 & Medium & nh1mS1132 & 2.13 & 49 & 94 & 3.33 & 0.59 & 0.26 & 0.03 & 4.21 & 1.07 & 0 & 6.3 & 11.531788 & 100 & 0 \\
\hline São Luiz & Vineyards & 1 & Medium & hmSl141A & 2.98 & 59 & 129 & 1.78 & 0.24 & 0.32 & 0.03 & 2.37 & 1.54 & 0 & 5.6 & 11.232868 & 100 & 1 \\
\hline São Luiz & Vineyards & 0 & Medium & nh1mSl142A & 3.05 & 52 & 368 & 2.42 & 0.59 & 0.51 & 0.06 & 3.57 & 1.59 & 0 & 6.2 & 11.131185 & 100 & 1 \\
\hline São Luiz & Vineyards & 1 & Gross & hgSl151A & 10.96 & 79 & 127 & 6.98 & 2.45 & 0.47 & 0.08 & 10.93 & 4.38 & 0.95 & 6.1 & 14.519386 & 91 & 1 \\
\hline São Luiz & Vineyards & 0 & Medium & nh1mSl152 & 1.57 & 8 & 74 & 1.71 & 0.77 & 0.20 & 0.07 & 2.76 & 0.96 & 0 & 5.6 & 9.4784083 & 100 & 0 \\
\hline São Luiz & Vineyards & 1 & Gross & hgSl241 & 16.37 & 152 & 767 & 6.12 & 3.73 & 0.88 & 0.13 & 10.87 & 6.22 & 0 & 6.3 & 15.262445 & 100 & 0 \\
\hline São Luiz & Vineyards & 0 & Medium & nh1mSl242 & 5.16 & 51 & 171 & 5.39 & 1.36 & 0.43 & 0.03 & 7.22 & 2.56 & 0 & 6.3 & 11.694377 & 100 & 0 \\
\hline São Luiz & Vineyards & 0 & Medium & nh1mS126A & 2.17 & 64 & 54 & 7.52 & 2.45 & 0.12 & 0.10 & 10.54 & 1.08 & 0.35 & 7.0 & 11.665733 & 97 & 1 \\
\hline São Luiz & Hedgerows & 0 & Gross & nh2gSIM1A & 9.02 & 4 & 48 & 3.12 & 1.36 & 0.14 & 0.10 & 4.72 & 4.15 & 0 & 5.4 & 12.601401 & 100 & 1 \\
\hline São Luiz & Hedgerows & 0 & Gross & nh2gSlM2D & 12.84 & 5 & 48 & 3.89 & 1.49 & 0.16 & 0.86 & 6.40 & 4.68 & 0 & 6.7 & 15.91753 & 100 & 4 \\
\hline
\end{tabular}


Table 1. Cont

\begin{tabular}{|c|c|c|c|c|c|c|c|c|c|c|c|c|c|c|c|c|c|c|}
\hline Farm Type & Soil Type & Herbicide Usage & Rapid Texture & Collection Site & OM & $\mathbf{P}$ & $\mathbf{K}$ & $\mathrm{Ca}^{2+}$ & $\mathrm{Mg}^{2+}$ & $\mathrm{K}^{+}$ & $\mathrm{Na}^{+}$ & ECEC & $\mathbf{N}$ & TA & $\mathrm{pH}$ & $\mathrm{C}: \mathrm{N}$ & DBS & $\begin{array}{c}\text { Fusarium oxysporum } \\
\text { Count }\end{array}$ \\
\hline São Luiz & Hedgerows & 0 & Gross & nh2gSIM3B & 8.55 & 2 & 52 & 3.18 & 1.39 & 0.29 & 0.14 & 5.50 & 3.86 & 0.50 & 6.0 & 12.848713 & 91 & 2 \\
\hline São Luiz & Hedgerows & 0 & Gross & nh2gSIM4A & 6.79 & 1 & 46 & 1.82 & 0.83 & 0.16 & 0.08 & 3.27 & 3.43 & 0.38 & 5.9 & 11.485962 & 89 & 1 \\
\hline Granja & Vineyards & 1 & Medium & hmGr21 & 1.41 & 48 & 408 & 3.5 & 1.0 & 0.9 & 0.4 & 5.87 & 0.84 & 0.09 & 5.8 & 9.7611238 & 98 & 0 \\
\hline Granja & Vineyards & 0 & Medium & nh1mGr22E & 1.10 & 24 & 145 & 3.2 & 0.8 & 0.4 & 0.3 & 5.25 & 0.68 & 0.585 & 5.1 & 9.4110118 & 89 & 5 \\
\hline Granja & Vineyards & 1 & Medium & hmGr31 & 1.19 & 6 & 133 & 2.4 & 1.0 & 0.3 & 0.3 & 4.30 & 0.76 & 0.315 & 4.6 & 9.0782211 & 93 & 0 \\
\hline Granja & Vineyards & 0 & Medium & nh1mGr32C & 0.98 & 11 & 60 & 3.6 & 0.8 & 0.2 & 0.3 & 5.28 & 0.69 & 0.338 & 4.6 & 8.2602087 & 94 & 3 \\
\hline Granja & Vineyards & 1 & Medium & $\mathrm{hmGr} 41$ & 2.07 & 22 & 207 & 1.7 & 0.7 & 0.7 & 0.4 & 4.29 & 1.28 & 0.72 & 4.7 & 9.37425 & 83 & 0 \\
\hline Granja & Vineyards & 0 & Medium & nh1mGr42C & 2.57 & 32 & 209 & 1.7 & 0.7 & 0.7 & 0.3 & 3.90 & 1.43 & 0.563 & 5.0 & 10.418747 & 86 & 3 \\
\hline Granja & Vineyards & 1 & Medium & hmGr51B & 1.05 & 30 & 175 & 1.6 & 0.5 & 0.4 & 0.3 & 3.48 & 0.71 & 0.63 & 5.0 & 8.590862 & 82 & 2 \\
\hline Granja & Vineyards & 0 & Medium & nh1mGr52D & 1.40 & 25 & 195 & 1.4 & 0.4 & 0.6 & 0.3 & 3.32 & 0.89 & 0.608 & 5.0 & 9.1003955 & 82 & 4 \\
\hline Granja & Vineyards & 1 & Medium & hmGr61 & 1.52 & 17 & 120 & 1.9 & 0.7 & 0.3 & 0.4 & 4.22 & 0.90 & 0.945 & 4.4 & 9.7769956 & 78 & 0 \\
\hline Granja & Vineyards & 0 & Medium & nh1mGr62E & 1.38 & 11 & 149 & 1.4 & 0.4 & 0.4 & 0.3 & 3.83 & 0.86 & 1.35 & 4.4 & 9.3015814 & 65 & 5 \\
\hline Granja & Vineyards & 1 & Medium & hmGr71A & 0.78 & 10 & 100 & 2.2 & 0.9 & 0.3 & 0.3 & 4.31 & 0.54 & 0.675 & 4.7 & 8.3326667 & 84 & 1 \\
\hline Granja & Vineyards & 0 & Medium & nh1mGr72C & 0.55 & 7 & 110 & 1.3 & 0.5 & 0.3 & 0.3 & 3.18 & 0.40 & 0.72 & 4.8 & 7.99936 & 77 & 3 \\
\hline Aciprestes & Vineyards & 1 & Medium & hmAc11 & 1.35 & 100 & 100 & 4.19 & 0.85 & 0.16 & 0.13 & 5.33 & 0.96 & 0 & 7.2 & 8.1347658 & 100 & 2 \\
\hline Aciprestes & Vineyards & 0 & Medium & nh1mAc12 & 2.08 & 96 & 108 & 4.48 & 1.36 & 0.21 & 0.03 & 6.08 & 1.13 & 0 & 7.0 & 10.68941 & 100 & 1 \\
\hline Aciprestes & Vineyards & 1 & Medium & $\mathrm{hmAc} 21$ & 2.32 & 90 & 84 & 6.11 & 1.07 & 0.15 & 0.06 & 7.38 & 1.17 & 0 & 7.5 & 11.511899 & 100 & 3 \\
\hline Aciprestes & Vineyards & 0 & Medium & nh1mAc22 & 3.04 & 106 & 72 & 6.54 & 1.71 & 0.13 & 0.15 & 8.53 & 1.54 & 0 & 7.3 & 11.453629 & 100 & 1 \\
\hline Aciprestes & Vineyards & 1 & Medium & hmAc3 & 2.55 & 214 & 104 & 4.67 & 0.96 & 0.20 & 0.04 & 5.87 & 1.36 & 0 & 7.2 & 10.888835 & 100 & 1 \\
\hline Aciprestes & Vineyards & 1 & Medium & $\mathrm{hmAc41}$ & 1.31 & 66 & 66 & 3.90 & 1.20 & 0.11 & 0.09 & 5.31 & 0.68 & 0 & 7.3 & 11.160872 & 100 & 5 \\
\hline Aciprestes & Vineyards & 0 & Medium & nh1mAc42 & 1.24 & 83 & 46 & 6.4 & 1.1 & 0.1 & 0.4 & 7.96 & 0.86 & 0 & 6.9 & 8.3714233 & 100 & 0 \\
\hline Aciprestes & Vineyards & 1 & Medium & hmAc51 & 0.51 & 17 & 127 & 3.94 & 1.55 & 0.09 & 0.11 & 5.68 & 0.33 & 0 & 7.3 & 8.9689794 & 100 & 0 \\
\hline Aciprestes & Vineyards & 0 & Medium & nh1mAc52 & 0.88 & 28 & 48 & 4.8 & 1.3 & 0.2 & 0.3 & 6.67 & 0.55 & 0 & 6.7 & 9.2719855 & 100 & 3 \\
\hline Aciprestes & Vineyards & 1 & Medium & hmAc61 & 0.99 & 91 & 76 & 5.84 & 1.44 & 0.12 & 0.09 & 7.49 & 0.69 & 0 & 7.0 & 8.3036835 & 100 & 0 \\
\hline Aciprestes & Vineyards & 0 & Medium & nh1mAc61 & 2.16 & 100 & 58 & 6.9 & 1.9 & 0.2 & 0.5 & 9.49 & 1.29 & 0 & 6.7 & 9.6891473 & 100 & 1 \\
\hline Aciprestes & Vineyards & 1 & Medium & hmAc71 & 1.46 & 59 & 96 & 4.78 & 1.44 & 0.11 & 0.06 & 6.40 & 0.93 & 0 & 7.2 & 9.0852946 & 100 & 0 \\
\hline Aciprestes & Vineyards & 0 & Medium & nh1mAc72 & 0.62 & 34 & 48 & 4.4 & 1.2 & 0.1 & 0.1 & 5.92 & 0.41 & 0 & 6.9 & 8.7797854 & 100 & 1 \\
\hline Aciprestes & Vineyards & 1 & Medium & $\mathrm{hmAc} 81$ & 1.98 & 206 & 159 & 6.18 & 1.33 & 0.13 & 0.07 & 7.71 & 1.27 & 0 & 7.3 & 9.0386469 & 100 & 0 \\
\hline Aciprestes & Vineyards & 0 & Medium & nh1mAc82 & 1.19 & 73 & 80 & 7.9 & 1.5 & 0.2 & 0.4 & 9.95 & 0.77 & 0 & 6.9 & 8.9603221 & 100 & 0 \\
\hline Aciprestes & Hedgerows & 0 & Medium & nh2mAcM1 & 2.62 & 12 & 92 & 4.08 & 1.44 & 0.18 & 0.06 & 5.77 & 1.27 & 0 & 6.8 & 11.9518 & 100 & 0 \\
\hline Aciprestes & Hedgerows & 0 & Gross & nh2gAcM2 & 1.61 & 4 & 66 & 3.07 & 1.87 & 0.14 & 0.04 & 5.12 & 0.93 & 0 & 6.7 & 10.063711 & 100 & 2 \\
\hline Aciprestes & Hedgerows & 0 & Medium & nh2mAcM3 & 1.75 & 20 & 123 & 3.39 & 1.28 & 0.23 & 0.03 & 4.93 & 0.91 & 0 & 6.7 & 11.130978 & 100 & 2 \\
\hline Aciprestes & Hedgerows & 0 & Medium & nh2mAcM4 & 0.56 & 4 & 56 & 3.30 & 1.81 & 0.10 & 0.03 & 5.24 & 0.38 & 0 & 6.6 & 8.6045747 & 100 & 1 \\
\hline
\end{tabular}

Note: herbicide applied (1) and no herbicide applied (0). Other representations are organic matter \% (OM), available phosphorous $\mathrm{mg} / \mathrm{kg}(\mathrm{P})$, available potassium mg/kg (K), exchangeable calcium ions $\mathrm{cmol} / \mathrm{kg}\left(\mathrm{Ca}^{2+}\right)$, exchangeable magnesium ions $\mathrm{cmol} / \mathrm{kg}\left(\mathrm{Mg}^{2+}\right)$, exchangeable potassium ions $\mathrm{cmol} / \mathrm{kg}\left(\mathrm{K}^{+}\right)$, exchangeable sodium ions $\mathrm{cmol} / \mathrm{kg}\left(\mathrm{Na}^{+}\right)$, effective cation exchange capacity $\mathrm{cmol} / \mathrm{kg}(\mathrm{ECEC})$, total nitrogen $\mathrm{g} / \mathrm{kg}(\mathrm{N})$, total acidity (TA), and degree of base saturation \% (DBS). 


\subsection{Effect of Soil Chemical Properties on Fungal Abundance}

Previously, a generalized linear model (GLM) was used to relate the count data of $F$. oxysporum abundance with soil chemical properties, followed by the stepwise procedure for the deletion of non-significant variables. The only significant soil properties observed were the two log-transformed variables (i.e., $\log \mathrm{C}: \mathrm{N}$ and $\log \mathrm{K}^{+}$). This analysis was followed by a GLMM with only $\log \mathrm{C}: \mathrm{N}$ and $\log \mathrm{K}^{+}$as the relevant soil properties, and the farm type as a random effect. For GLMM, the global significance of the model was $p<0.001$ (Wald $\chi^{2}=17.516$, d.f. $=2$ ), and the AIC value was 228.7. Higher $\log$ C:N significantly promoted while higher exchangeable $\log \mathrm{K}^{+}$significantly inhibited the abundance of $F$. oxysporum mycoses in insect larvae, respectively (Figure 1). The statistical values of the significance for the log-transformed variables were Wald $\chi^{2}=15.468$, d.f. $=1$, and $p<0.001$ for $\log$ $\mathrm{C}: \mathrm{N}$, and Wald $\chi^{2}=6.976$, d.f. $=1$, and $p=0.008$ for $\log \mathrm{K}^{+}$. Other relevant values for these significant variables were estimate $=3.8238$, standard error $=0.9722$, and $\mathrm{Z}$ value $=3.933$ for $\log \mathrm{C}: \mathrm{N}$; and estimate $=-0.7271$, standard error $=0.2753$, and Z-value $=-2.641$ for $\log \mathrm{K}^{+}$.

\section{A)}
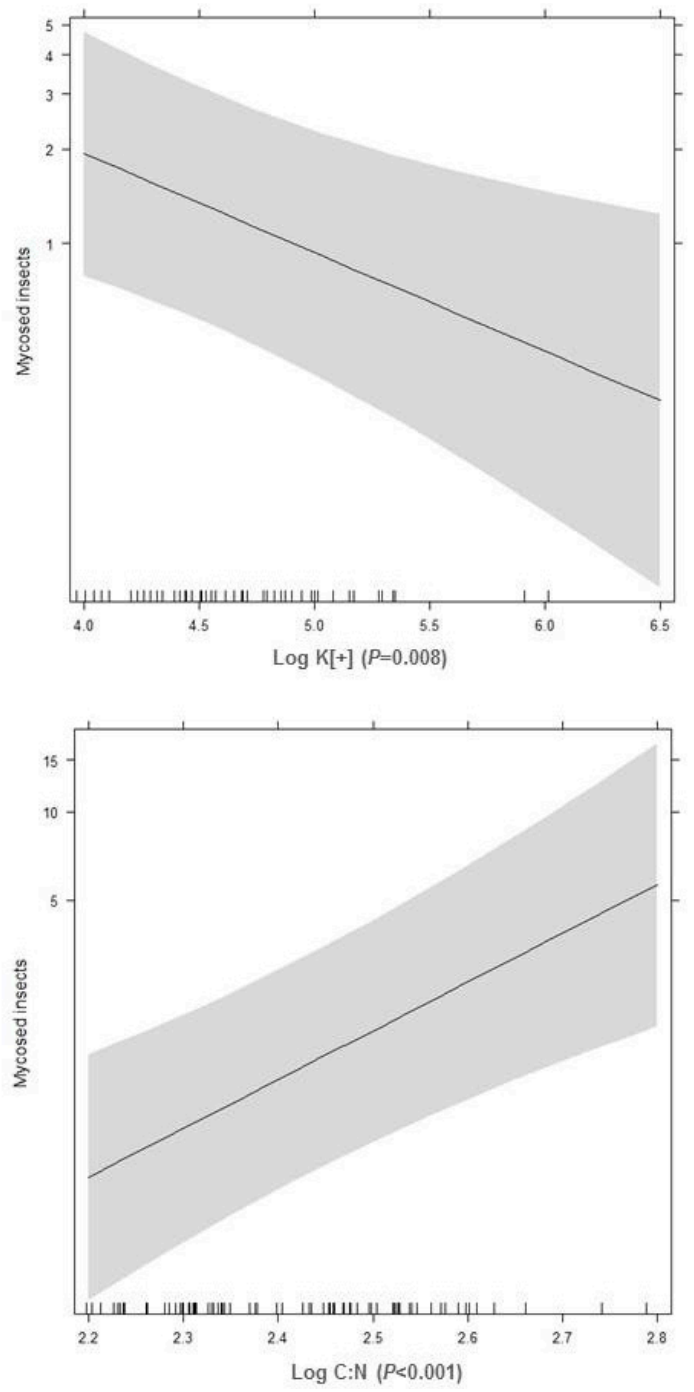

Figure 1. Cont. 
B)



Figure 1. Variations in the number of insect larvae mycosed by Fusarium oxysporum with respect to the significant soil chemical variables. (A) The trend of larval mycoses with respect to the soil variables. (B) Scatter-plot of the number of larval mycoses by Fusarium oxysporum (mentioned as counts) at 80 soil sampling sites, with respect to the significant soil variables.

\section{Discussion}

Biological communities in soils are likely to be the most complex. Microorganisms in the soils are extremely diverse, and they contribute to numerous ecosystem services that are critical to the sustainable functioning of both natural as well as managed ecosystems [17]. Agroecosystems, for example, constantly lose nutrients through leaching, run-off, denitrification, removal of crop harvest, and residues, and hence are dependent on continuous external inputs of nutrients. Such losses are likely to affect lower trophic levels, and ultimately influence different ecosystems services, such as pest suppression [18]. Soil microbes can affect crop yield, either (a) directly, e.g., as crop pathogens; or (b) indirectly, by participating in soil structure modification, carbon and nutrient cycles, and food web interactions. In either of these cases, soil microbes ultimately influence crop productivity $[17,19,20]$. To bridge the gaps between these phenomena, the current study focuses on the soil chemical properties with respect to the abundance of IPF F. oxysporum.

The most significant soil variable was the C:N $(p<0.001)$, which promoted the abundance of mycoses in insect larvae. Nitrogen is essential to plant growth and added as fertilizers in soils, if necessary. However, it was noticed that addition of the NPK fertilizers eventually reduces the density of entomopathogens-for example, nematodes [21]. Moreover, fertilizing soils tend to reduce the internal biological control within agroecosystems [18]. Higher organic matter, and hence, the higher organic carbon, increases the cation exchange capacity of the soils, which ultimately increases fungal conidia attachment [8]. Therefore, an increase in $\mathrm{C}$ and a decrease in $\mathrm{N}$, which lead to a higher $\mathrm{C}: \mathrm{N}$, eventually facilitated the abundance of IPF F. oxysporum in our study.

Modeling has been an integral part in predicting phenomena in entomology. For example, it has been used previously to estimate flight phenology of world-famous insect pests, such as the European grapevine moth, or Lobesia botrana (Denis and Schiffermüller) (Lepidoptera: Tortricidae), in the Douro vineyards [13]. A generalized linear mixed model, with a previous GLM stepwise deletion of non-significant variables, provides a better outlook towards finding the variables that are significantly affecting the data. The stepwise GLM procedures allow the discarding of effects that do not differ significantly from zero. Further usage of a less complex model, such as GLMM, which is widely used in ecology [15], allowed improving the model and generalizing conclusions. 


\section{Materials and Methods}

\subsection{Sampling Site}

Soils were initially collected in a previous study [1]. In the present study, the four farms, i.e., Aciprestes $\left(41^{\circ} 12^{\prime} 25.2^{\prime \prime} \mathrm{N} 7^{\circ} 25^{\prime} 55.2^{\prime \prime} \mathrm{W}\right)$, Carvalhas $\left(41^{\circ} 11^{\prime} 12.9^{\prime \prime} \mathrm{N} 7^{\circ} 32^{\prime} 41.5^{\prime \prime} \mathrm{W}\right)$, São Luiz $\left(41^{\circ} 9^{\prime} 22^{\prime \prime}\right.$ N $\left.7^{\circ} 36^{\prime} 55^{\prime \prime} \mathrm{W}\right)$, and Granja $\left(41^{\circ} 15^{\prime} 18^{\prime \prime} \mathrm{N} 7^{\circ} 28^{\prime} 34^{\prime \prime} \mathrm{W}\right)$ were considered. These farms are located in the "Cima Cargo" region of the Douro vineyards of Portugal. The mean annual rainfall and temperature at the farms of São Luiz, Carvalhas, and Aciprestes ranges between 800-1000 mm and $14-16{ }^{\circ} \mathrm{C}$, respectively. The Granja farm records 1000-1200 mm mean annual rainfall and temperatures ranging from $12-14{ }^{\circ} \mathrm{C}$. Information on any chemical treatments of the soils is provided in the Supplementary Materials (see Table S1).

\subsection{Fungal Isolation, Identification, and Screening}

Soils were brought within the campus, and approximately one $\mathrm{kg}$ of those soils was air-dried and preserved for physicochemical analyses. For isolation of the entomopathogenic F. oxysporum, the remaining soil portions were equilibrated for moisture overnight, and then baited with eight late-instar larvae of G. mellonella and eight late-instar larvae of Tenebrio molitor Linnaeus (Coleoptera: Tenebrionidae) within $24 \mathrm{~h}$, as described in a previous study [1]. In brief, two sets of four insect larvae of each bait insect were used. To reduce the tendency of silk web formation, the larvae of G. mellonella were given a heat shock in the water bath at $56{ }^{\circ} \mathrm{C}$ prior to baiting. Soils were kept at a temperature of $22{ }^{\circ} \mathrm{C}$ and a relative humidity of $85 \%$, in the dark inside an environmental chamber (Panasonic MLR-352H-PE). Bowls were frequently agitated and inverted to maximize larval reach for fungal spores in soils. The total incubation period was three weeks. Insect cadavers were monitored every second day to retrieve any mycosed larvae, and to discard cadavers that were infected by entomopathogenic nematodes. Cadavers with a foul smell were also regularly discarded. These schedules were monitored rigorously. Insect cadavers that were suspected to be mycosed by the fungus were then washed for three minutes with $1 \% \mathrm{NaOCl}$, followed by three distinct washes with $100 \mathrm{~mL}$ of sterilized water. Subsequent culturing on potato dextrose agar was conducted until pure cultures were obtained. Insects were procured as described in another study [2]. Fusarium oxysporum have diverse ecological roles, and therefore, insect baiting seemed a better approach than soil suspension culture or a DNA-based approach for the accurate functional annotation of the obtained F. oxysporum isolate. Fungus was identified using morphological and molecular techniques, as described previously [1]. Infectivity of the isolated fungi were further confirmed by Koch's postulates, as previously described [1,22,23]. Only the fungi that were found to be pathogenic after confirming Koch's postulates were further considered in the study. A total of 80 samples were tested for the presence and abundance of entomopathogenic F. oxysporum.

\subsection{Soil Analyses and Calculations}

Soil pH was determined one hour after preparing a soil-water suspension. Organic matter

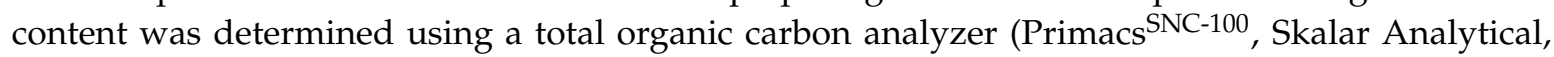
Breda, The Netherlands). Total nitrogen was assessed by the Kjeldahl method, and the quantification was done using molecular absorption spectrophotometry [24]. The Egnér-Riehm method was used to extract $\mathrm{P}$ and $\mathrm{K}$, and a spectrophotometer and a flame emission photometer (iCE ${ }^{\mathrm{TM}} 3300$ AAS, Thermo Scientific $^{\mathrm{TM}}$, Breda, North Brabant, The Netherlands) was used for their respective determination. Exchangeable cations, or exchangeable bases, were measured by atomic absorption spectrophotometry, following the ammonium acetate extraction at a $\mathrm{pH}$ of 7.0 [25]. Titration method described in Thomas was used to determine exchangeable acidity [26]. Effective cation exchange capacity was calculated by summing exchangeable bases and exchangeable acidity. The degree of base saturation was measured by summing the exchangeable bases, dividing it by the ECEC, and then multiplying by 100. 


\subsection{Data Analyses}

The abundance of the infected insects was analyzed using a generalized liner mixed model (GLMM), assuming a Poisson distribution for count data with a log link function. Model assumptions were inspected by visualizing residual plots. Soil properties were used as independent variables, herbicide application was considered as the fixed effect, and the farm type was considered as a random effect. The analysis started fitting the full model, which included all independent variables, followed by the stepwise procedure to remove non-significant variables [27]. The significance of the model was obtained using a Wald test, generated by the likelihood ratio tests of the full model with and without the explanatory variable. The analyses were performed in R (version 3.2.2) using the "MASS" package [28] and the "lme4" package [29].

\section{Conclusions}

Interactions between plants and microbes are quite complex, and it is necessary to move forward from a simplistic view of an individual plant-microbe interaction to all factors influencing agroecosystems. Soil, its microbes, and plants all work in coherence, and influence various exchanges contributing to plant health and productivity [30]. Soil provides fundamental ecosystem services, which include control of pests and diseases, nutrient cycling, and transformation of toxic materials and organic compounds. Microbes play a critical role in most of the soil processes. In this study, soil chemical properties affecting the presences of IPF F. oxysporum were investigated, and few significant findings could be made. Overall, it was noticed that entomopathogenic F. oxysporum is robust to most of the agricultural disturbances, although higher $\mathrm{C}: \mathrm{N}$ and less exchangeable $\mathrm{K}^{+}$might facilitate its natural abundance. This study suggests that IPF F. oxysporum can survive effectively in different soils, which further highlights its capabilities as an excellent soil saprophyte in the absence of host insects, as hinted previously [5]. This kind of approach can be extended to other beneficial soil microbes. Predicting soil microbial quality based on soil chemical properties could be a promising approach in the development of the methods for sustainable agriculture. Authors also suggest the use of GLMM in similar studies focusing on count data profiles, while accessing the factors affecting the abundance of the microbes of interest.

Supplementary Materials: The following are available online at http:/ /www.mdpi.com/2076-0817/7/4/89/s1, Table S1: Chemicals applied in the farms of the Douro wine region.

Author Contributions: Conceptualization: L.S., I.O., F.R., L.T. and G.M.; methodology: L.S., I.O., F.R. and G.M.; software: L.S. and I.O.; validation: L.S., I.O., F.R. and G.M.; formal analysis: L.S. and I.O.; investigation: L.S., L.T. and G.M.; resources: F.R., L.T. and G.M.; data curation: L.S. and I.O.; writing-original draft preparation: L.S.; writing-review and editing: I.O., F.R., L.T. and G.M.; visualization: L.S. and I.O.; supervision: L.T. and G.M.; project administration: L.T. and G.M.; funding acquisition: L.T. and G.M.

Funding: Research was funded by the National Funds of the FCT (Portuguese Foundation for Science and Technology) under the projects UID/MULTI/04621/2013 and UID/AGR/04033/2013; the project EcoVitis-Maximizing ecosystem services in "Douro Demarcated Region" vineyards, funded by FEADER and by National Funds under the Rural Development Programme (PRODER)-PA 24043, 2011-2014, under the fellowship BI/PRODER/Projeto24043/UTAD/2012; and from European Investment Funds by FEDER/COMPETE/POCI Operacional Competitiveness and Internationalization Programme, under the Project POCI-01-0145-FEDER-006958.

Acknowledgments: The work is a part of L.S.'s Ph.D. dissertation at the University of Trás-os-Montes and Alto Douro, UTAD, Vila Real, Portugal. The authors would like to thank three anonymous reviewers for providing meaningful comments for the improvement of this manuscript. The authors would also like to thank the technicians of the Sogevinus Finewines SA and Real Companhia Velha for their constant cooperation during the investigation.

Conflicts of Interest: The authors declare no conflict of interest. 


\section{References}

1. Sharma, L.; Oliveira, I.; Torres, L.; Marques, G. Entomopathogenic fungi in Portuguese vineyards soils: Suggesting a 'Galleria-Tenebrio-bait method' as bait-insects Galleria and Tenebrio significantly underestimate the respective recoveries of Metarhizium (robertsii) and Beauveria (bassiana). MycoKeys 2018, 38, 1-23. [CrossRef]

2. Sharma, L.; Gonçalves, F.; Oliveira, I.; Torres, L.; Marques, G. Insect-associated fungi from naturally mycosed vine mealybug Planococcus ficus (Signoret) (Hemiptera: Pseudococcidae). Biocontrol Sci. Technol. 2018, 28, 122-141. [CrossRef]

3. Tiago, P.V.; Medeiros, L.V.; Carneiro Leão, M.P.; Santos, A.C.; da Costa, A.F.; de Oliveira, N.T. Polymorphisms in entomopathogenic fusaria based on inter simple sequence repeats. Biocontrol Sci. Technol. 2016, 26, 1401-1410. [CrossRef]

4. O'Donnell, K.; Humber, R.A.; Geiser, D.M.; Kang, S.; Park, B.; Robert, V.A.R.G.; Crous, P.W.; Johnston, P.R.; Aoki, T.; Rooney, A.P.; et al. Phylogenetic diversity of insecticolous fusaria inferred from multilocus DNA sequence data and their molecular identification via Fusarium-ID and Fusarium MLST. Mycologia 2012, 104, 427-445. [CrossRef] [PubMed]

5. Teetor-Barsch, G.H.; Roberts, D.W. Entomogenous Fusarium species. Mycopathologia 1983, 84, 3-16. [CrossRef] [PubMed]

6. Navarro-Velasco, G.Y.; Prados-Rosales, R.C.; Ortíz-Urquiza, A.; Quesada-Moraga, E.; Di Pietro, A. Galleria mellonella as model host for the trans-kingdom pathogen Fusarium oxysporum. Fungal Genet. Biol. 2011, 48, 1124-1129. [CrossRef] [PubMed]

7. Jaronski, S.T. Soil ecology of the entomopathogenic ascomycetes: A critical examination of what we (think) we know. In Use of Entomopathogenic Fungi in Biological Pest Management; Maniana, K., Ekesi, S., Eds.; Research SignPosts: Trivandrum, India, 2007; pp. 91-144. ISBN 978-8-13-080192-6.

8. Quesada-Moraga, E.; Navas-Cortés, J.A.; Maranhao, E.A.A.; Ortiz-Urquiza, A.; Santiago-Álvarez, C. Factors affecting the occurrence and distribution of entomopathogenic fungi in natural and cultivated soils. Mycol. Res. 2007, 111, 947-966. [CrossRef] [PubMed]

9. Jabbour, R.; Barbercheck, M.E. Soil management effects on entomopathogenic fungi during the transition to organic agriculture in a feed grain rotation. Biol. Control 2009, 51, 435-443. [CrossRef]

10. Oddsdottir, E.S.; Nielsen, C.; Sen, R.; Harding, S.; Eilenberg, J.; Halldorsson, G. Distribution patterns of soil entomopathogenic and birch symbiotic ectomycorrhizal fungi across native woodlandand degraded habitats in Iceland. Icel. Agric. Sci. 2010, 23, 37-49.

11. Garrido-Jurado, I.; Torrent, J.; Barrón, V.; Corpas, A.; Quesada-Moraga, E. Soil properties affect the availability, movement, and virulence of entomopathogenic fungi conidia against puparia of Ceratitis capitata (Diptera: Tephritidae). Biol. Control 2011, 58, 277-285. [CrossRef]

12. Clifton, E.H.; Jaronski, S.T.; Hodgson, E.W.; Gassmann, A.J. Abundance of soil-borne entomopathogenic fungi in organic and conventional fields in the midwestern USA with an emphasis on the effect of herbicides and fungicides on fungal persistence. PLOS ONE 2015, 10, e0133613. [CrossRef] [PubMed]

13. Carlos, C.; Gonçalves, F.; Oliveira, I.; Torres, L. Is a biofix necessary for predicting the flight phenology of Lobesia botrana in Douro demarcated region vineyards? Crop Prot. 2018, 110, 57-64. [CrossRef]

14. Garrido-Jurado, I.; Valverde-García, P.; Quesada-Moraga, E. Use of a multiple logistic regression model to determine the effects of soil moisture and temperature on the virulence of entomopathogenic fungi against pre-imaginal Mediterranean fruit fly Ceratitis capitata. Biol. Control 2011, 59, 366-372. [CrossRef]

15. Bolker, B.M.; Brooks, M.E.; Clark, C.J.; Geange, S.W.; Poulsen, J.R.; Stevens, M.H.H.; White, J.-S.S. Generalized linear mixed models: A practical guide for ecology and evolution. Trends Ecol. Evol. 2009, 24, 127-135. [CrossRef] [PubMed]

16. Oliveira, T.; Moral, R.; Hinde, J.; Demétrio, C.; Zocchi, S.S.; Zanardo, A.B.; Delalibera, I. Generalized linear mixed models applied to overdispersed proportion data in a fungal occurrence study. In Proceedings of the 30th International Workshop on Statistical Modelling, Linz, Austria, 6-10 July 2015; Friedl, H., Wagner, H., Eds.; Johannes Kepler Universität: Linz, Austria, 2015; Volume 2.

17. Barrios, E. Soil biota, ecosystem services and land productivity. Ecol. Econ. 2007, 64, 269-285. [CrossRef] 
18. Birkhofer, K.; Bezemer, T.M.; Bloem, J.; Bonkowski, M.; Christensen, S.; Dubois, D.; Ekelund, F.; Fließbach, A.; Gunst, L.; Hedlund, K.; et al. Long-term organic farming fosters below and aboveground biota: Implications for soil quality, biological control and productivity. Soil Biol. Biochem. 2008, 40, 2297-2308. [CrossRef]

19. Carlos, C.G.F.; Sousa, S.; Salvação, J.; Sharma, L.; Soares, R.; Manso, J.; Nóbrega, M.; Lopes, A.; Soares, S.; Aranha, J.; et al. Environmentally safe strategies to control the European grapevine moth, Lobesia botrana (Den. \& Schiff.) in the Douro demarcated region. Cienc. Tec. Vitivinic. 2013, 1006-1011.

20. Gonçalves, F.; Carlos, C.; Aranha, J.; Torres, L. Does habitat heterogeneity affect the diversity of epigaeic arthropods in vineyards? Agric. For. Entomol. 2018, 20, 366-379. [CrossRef]

21. Bednarek, A.; Gaugler, R. Compatibility of soil amendments with entomopathogenic nematodes. J. Nematol. 1997, 29, 220-227. [PubMed]

22. Sun, B.-D.; Liu, X.-Z. Occurrence and diversity of insect-associated fungi in natural soils in China. Appl. Soil Ecol. 2008, 39, 100-108. [CrossRef]

23. Goble, T.A.; Dames, J.F.; Hill, M.P.; Moore, S.D. The effects of farming system, habitat type and bait type on the isolation of entomopathogenic fungi from citrus soils in the eastern Cape province, South Africa. BioControl 2010, 55, 399-412. [CrossRef]

24. Bremner, J.M. Nitrogen-total. In Methods of Soil Analysis Part 3-Chemical Methods; Sparks, D.L., Page, A.L., Helmke, P.A., Loeppert, R.H., Eds.; Soil Science Society of America, American Society of Agronomy: Madison, WI, USA, 1996; pp. 1085-1121.

25. Bower, C.A.; Reitemeier, R.F.; Fireman, M. Exchangeable cation analysis of saline and alkali soils. Soil Sci. 1952, 73, 251-262. [CrossRef]

26. Thomas, G.W. Soil pH and soil acidity. In Methods of Soil Analysis Part 3-Chemical Methods; Sparks, D.L., Page, A.L., Helmke, P.A., Loeppert, R.H., Eds.; Soil Science Society of America, American Society of Agronomy: Madison, WI, USA, 1996; pp. 475-490.

27. Crawley, M.J. Generalized linear models. In The R book; Crawley, M.J., Ed.; John Wiley \& Sons: Chichester, UK, 2007; pp. 511-526.

28. Venables, W.N.; Ripley, B.D. Modern Applied Statistics with S, 4th ed.; Springer: New York, NY, USA, 2002; ISBN 978-0-38-721706-2.

29. Bates, D.; Mächler, M.; Bolker, B.; Walker, S. Fitting linear mixed-effects models using lme4. J. Stat. Softw. 2015, 67, 1-48. [CrossRef]

30. Chaparro, J.M.; Sheflin, A.M.; Manter, D.K.; Vivanco, J.M. Manipulating the soil microbiome to increase soil health and plant fertility. Biol. Fertil. Soils 2012, 48, 489-499. [CrossRef] 